Embodied care : affective touch as a facilitating resource for interaction between caregivers and residents in a care home for older adults

Mononen, Kaarina

2019-06-22

Mononen , K 2019 , ' Embodied care : affective touch as a facilitating resource for interaction between caregivers and residents in a care home for older adults ', Linguistics vanguard :

multimodal online journal , vol. 5 , no. s2 , 20180036 . https://doi.org/10.1515/lingvan-2018-0036

http://hdl.handle.net/10138/326927

https://doi.org/10.1515/lingvan-2018-0036

unspecified

publishedVersion

Downloaded from Helda, University of Helsinki institutional repository.

This is an electronic reprint of the original article.

This reprint may differ from the original in pagination and typographic detail.

Please cite the original version. 


\title{
Kaarina Mononen*
}

\section{Embodied care: affective touch as a facilitating resource for interaction between caregivers and residents in a care home for older adults}

https://doi.org/10.1515/lingvan-2018-0036

Received May 16, 2018; accepted December 13, 2018

\begin{abstract}
This article analyses how caregivers use affective touch as a resource to facilitate interaction. Through touch, caregivers construct positive socio-emotional relationships with their residents. The analysis of micro-level interaction is based on an interactional sociolinguistic framework, and reveals how caregivers display affection and intimacy while assisting the residents in everyday situations in a care home. All of the examples involve touching a person's shoulder, stroking or giving half-embraces, typical resources used to construct affiliation between caregivers and residents. This article illustrates how affective touch facilitates interaction by regulating participation and calming down residents, by mitigating the controlling aspect of caring, and by fostering a positive interpersonal relationship. The care situations presented in this article contain crucial pauses within talk that are used to construct a peaceful atmosphere. During these crucial moments, embodied action effectively indicates an orientation to listening and establishes a presence to accomplish the actions in that situational talk. This analysis contributes to the studies on embodied interaction and on interpersonal relationships in care for older adults. ${ }^{1}$
\end{abstract}

Keywords: language and aging; care home; interaction; touch; affective

\section{Introduction}

Few studies have analysed the combination of touch and socio-emotional relationships between caregivers and residents in a care home. This article increases our understanding of these affective factors. The main question concerns how affective touch is used as an interactional resource in displaying positive affiliation between residents and caregivers in everyday encounters. My focus is on the affective touch that can help to accomplish a practical task and that serves as one resource to display empathy with other communicative means, such as words, intonation and gestures.

Previous research has emphasized that an essential part of care is relational work (see for example Ward et al. 2008; Nakrem et al. 2011; Marsden and Holmes 2014). This requires getting to know the other interactant personally, also requiring that residents should not be regarded as a homogenous group (Harwood 2007: 43-44; Coupland 2011: ix), and that individual differences among caregivers cannot be ignored. Studies of interaction between caregivers and care recipients have reported on aspects of interaction such as the importance of supporting a care receiver's autonomy (Heinemann 2011), a careworker's creativity in utilising multilingual resources with an older immigrant (Jansson 2014), and caregivers' response practices to confabulations that are used to support a person who has dementia (Lindholm 2015). Embodied interaction has not yet been a focus of extensive research. Researchers in nursing studies have used interviews to analyse nonverbal communication (for example, Gleeson and Higgins 2009), and some experiments have been reported

1 I would like to thank Camilla Lindholm, an anonymous reviewer as well as Maria Frick and Hanna Lappalainen for valuable comments on the earlier versions of this article.

*Corresponding author: Kaarina Mononen, University of Helsinki, Helsinki, Finland, E-mail: kaarina.mononen@helsinki.fi. https://orcid.org/0000-0002-7214-0446 
(for example, see Langland and Panicucci 1982). Research has also been conducted on communication strategies, both verbal and non-verbal (Wilson et al. 2013). Furthermore, experiments and self-report surveys have been used to analyse therapeutic communication (for example, see Levy-Storms 2008).

Human interaction consists of an interplay between different, layered resources in a specific context. Touching is a special resource used to invoke interpersonal relationships that shifts focus away from institutional tasks, creates affiliation between interactants and thus contributes overall to good care (Heinemann 2007, Heinemann 2009; Backhaus 2011: 142; Coupland 2011: xi). I argue that assisting offers a natural opportunity to display intimacy. However, touch is a sensitive resource, and the question of displaying intimacy is complex in contexts that have institutional and interpersonal requirements that need to be met (compare Backhaus 2009; Marsden and Holmes 2014). ${ }^{2}$ Touch is also inherently dialogical and may threaten "the balance of intimacy" (Linell 2009: 20-21; Cekaite 2016: 31). Other factors that warrant consideration are individual and cultural differences (Gleeson and Higgins 2009: 388). Hence, understanding the dimensions of touch requires a careful analysis on the micro-level, as well as recognition of the norms involved in the community of practice. This article is based on the principle that communication is an embodied social action, and touch is one resource used to make an argument or action understandable (see for example Goodwin 2000). Scholars have increasingly become interested in embodied action, particularly in the research on social interaction (Nevile 2015).

In the following, I first closely examine the specific aspects of affective touch in light of previous research. In Section 3, I introduce the data and methods. Section 4 presents a discussion of how affective touch functions as part of building positive relationships in care encounters. The focus is first on the participation, then on caring for the emotional wellbeing of the resident. The discussion section provides a summary of the main findings.

\section{Studying affective touch}

Touching is a normal practice during care of older adults (Gleeson and Timmins 2004a: 21), and it relates to physical assisting as well as to emotional care, which I consider here to be relationship-building. ${ }^{3}$ I concentrate on affective touch, which contributes an intimate and caressing aspect to the interaction, and this type of touching can also be seen as being affectionate. Depending on the action, different types of touch can serve as displays of affection and are socioemotional, but hugs and caresses in particular can be interpreted in this manner, as they construct relatedness markedly and in an embodied way (Cekaite 2015: 154; Goodwin 2017).

Touch highlights presence, and it is a resource for participants to orient to each other and away from others who are present in a situation (Goffman 1964: 135; Peräkylä and Stevanovic 2016: 38, 45). Nursing studies adopt the term therapeutic presence to describe a nurse's ability to maintain an "emotionally supportive environment" (Delgado et al. 2017: 83) and the ability to help clients "feel affirmed, valued, and understood" (Chochinov et al. 2013: 1710). Touching can help to create this type of emotional situation. For example, Langland and Panicucci (1982) reported that when a verbal request was accompanied by a light touch, this increased nonverbal communication among the confused older adults. In fact, affective touch has been mentioned as a recommended therapeutic communication technique (Levy-Storms 2008), and comfort touch has been identified as a non-verbal communication strategy in assisting patients who have Alzheimer's (Wilson et al. 2013).

Researchers in interactional studies have studied touch in communicative environments such as childadult interactions (McIlvenny 2009; Tulbert and Goodwin 2011; Cekaite 2015, Cekaite 2016; Cekaite and Holm

2 Many studies identify the difference between institutional and non-institutional talk (see, for example, Grainger 1993; Ward et al. 2008; see Backhaus 2011: 133 for a summary of this distinction).

3 Early nursing studies use the term non-necessary touch to describe a "primarily affective" touch, "a form of personal contact" (Barnett 1972: 199), a term which does not seem to recognise personal relationships as being valuable (see also Routasalo 1996; for a critique, see Gleeson and Timmins 2004b: 544). 
2017; Goodwin 2017). Touching in these contexts is also a resource for affection, even though these studies have focussed more on the regulation of attention and on controlling behaviour. Overall, the sensitivity and regulation of emotions is connected to touching in a way that can serve as a resource to mitigate the abruptness of a task (Goodwin 2006), and as such it is particularly useful during face-threatening moments.

Goffman (1971: 62-94) analysed "supportive interchanges", specifically greetings and farewells, which are used for bonding, and these rituals naturally include embodied behaviour. Goodwin (2017) concentrates on cases of family members displaying affection by hugging, and she observes that the grooming between adults and children occasionally shifts into a caress (2017: 95). Cekaite and Holm (2017) analyse how caregivers responded to crying children in ways such as stroking them, and their study reveals how affective intensity varies according to the duration and timing.

While caregivers use affective touch in different contexts, it is important to remember that regardless of external similarities, care for older adults is fundamentally different from childcare. Care for older adults entails maintaining capabilities, whereas care for children involves teaching them new abilities. However, sensitivity to an individual's needs is crucial in both.

Institutional routines affect the dynamics of haptic behaviour, including the affective uses of touch. For instance, Goffman (1967: 73-75) reports on a touch system that occurred in a hospital where doctors held a position that allowed them to display support and comfort through touching their patients, but it was not suitable for the patients to reciprocate or to initiate this type of contact with their doctors. The same questions are relevant in a care home: a caregiver naturally initiates an affective touch, but it is unusual for a resident to initiate such a touch. It is obvious that a care home also maintains its own unwritten rules for displaying intimacy. Overall, a care home in which all the spheres of life occur within the same institution ("a total asylum"; Goffman 1961: 17) causes both threats as well as opportunities to acknowledge individuality. On the one hand, in that type of institution, it is possible to get to know people thoroughly (if there is not a high turnover of staff), and on the other hand, it develops its own practices and routines which might be difficult to question. "Acquaintanceship" or "knowership" is assumed - people know their rights and obligations as caregivers and residents (see Goffman 1983: 13), but the degree of intimacy and proximity remains individual and situational.

One feature often accompanying vocal elderspeak that researchers have analysed is touch by caregivers, particularly patting (Ryan et al. 1995: 154; Marsden and Holmes 2014: 19). When this interaction is examined at a microlevel, however, touching exhibits different nuances, and my aim is to demonstrate how affective touching between a caregiver and a resident in a care home creates co-presence and facilitates mutual understanding. I will compare the examples presented here to other cases and to the overall picture; the common features and specific aspects of using affective touch will be discussed in Section 4.

\section{Data and methods}

The data were collected from 2015 to 2016 in a care home in Finland. The data were recorded either by myself, with my assistant, or by my assistant alone. I made notes after visits as a part of ethnographic observation (see for example Lindholm 2016), and I also obtained additional information from my assistant. At the end of the data collection period, I conducted a background interview with the charge nurse. The interactional data consist of 55 hours of videotaped conversations held in public spaces. All personal information has been anonymised. The staff collected individual consents, and we tried to be sensitive to the situations we were recording, and explained our aims when needed. For example, our video equipment served as a source of frequent conversations with the residents. We became acquainted with the residents and chatted with them. We also talked with members of the staff, which clarified our presence in the institution. It is important to mention that this department of the institution had participated in other types of research previously and appeared to be positively oriented towards research.

Touching and embodied encounters became of interest to me when I collected pilot data on a home help service. For the current study, I have selected the episodes that include touch from my data and analysed the function of touch in each case. The collection was videotaped during a period of 28 days, and in 97 instances 
touch clearly occurred between the caregiver and resident. Out of these, approximately a fifth of the cases (24 encounters) involved the same interactants who used touch to communicate several times during longer encounters without interruptions, when a caregiver exited the situation. In a majority of these cases, touching was connected to assisting a resident, but the interpersonal aspect was intertwined. I observed that the situations where touching included affection were particularly relevant. In my data, I identified instances in which the caregiver embraced and stroked a resident. Thus, in over a third of the encounters in my collection, touching was expressed in a particularly intimate way. In addition to these, there is a continuum from embracing to putting one's hand on a resident's shoulder and the affective functions can be sometimes similar in those types of cases. Nonetheless, I have categorised the occurrences according to the position clearly visible as an embrace, as in the following:

\begin{tabular}{lr}
\hline Type of touching & Occurrences \\
\hline Embracing (partly or fully) & 19 \\
Stroking & 15 \\
Stroking \& embracing & 5 \\
Touching otherwise & 58 \\
Total number of encounters with touching & 97 \\
\hline
\end{tabular}

The three episodes analysed in this article are extracts from the collection used to illustrate situations that clearly involve affectionate touching, particularly stroking and embracing. All of the episodes are part of longer encounters, and this is why the touching is expressed in several different ways. These examples highlight affectionate touch as a part of care in different assisting situations and they reveal how touch is intertwined with the greater overall aims in those situations. Furthermore, the examples illustrate how the affective aspect of touch varies.

The method adopted in the article is interactional sociolinguistics, which is an approach that considers the surroundings and contextualisation processes (Gumperz 1982: 130-152, Gumperz 2001: 218). This article discusses how touch is contextualised in the relationship between the caregiver and the care recipient. I also apply conversation analytic methods that rely on the research of embodied interaction (for example, see Goodwin 2000, Goodwin 2007; Goodwin 2006; Meyer et al. 2017).

My starting point is to detect positive practices (compare for example Yu et al. 2018) that reveal how caregivers assist their residents smoothly, express friendliness as well as how they take into account the individual. This offers a more constructive basis for discussion about care for older adults. The aim is to discuss interaction on its own terms and to avoid focusing on loss and decay (de Bot and Makoni 2011). That is, I aim not to emphasize negative aspects but to reveal the possibilities in interaction when interactants have different capacities.

\section{Analysis}

The following analysis demonstrates how affective touching regulates participation and constructs interpersonal relationships in three specific cases: when assisting care home residents in eating, when closing an interaction between caregivers and residents, and when calming down residents. The main types of affective touch identified in this study are calming and caressing. These contribute to organising interaction when helping a person to eat or when closing an encounter, and these types of uses are especially prominent as part of interpersonal action. Stroking and embracing are typical means of realising this type of affective touch. However, the boundaries between affectionate and non-affectionate touch are fuzzy. Sometimes when a caregiver merely places a hand on a resident's shoulder, this can be affective; the types of touching fall along a continuum and are intertwined with other resources. In all of the cases presented here, touching constructs a positive relationship between interactants who display their co-presence differently. 


\subsection{Affective touch regulating participation}

As the older adults have different capacities, such as cognitive or hearing impairments, their care situations vary and occasionally require longer negotiation. Example 1 illustrates how both friendliness and a peaceful atmosphere are present when a caregiver, Saara, regulates participation and attempts to undertake a relevant action, having a meal, by touching the resident named Ruusa while helping her eat. Saara approaches Ruusa and interrupts her singing initially by stroking her head (line 2).

(1)

R: Ruusa, resident, S: Saara, caregiver

$01 \mathrm{R}:$

va:lit-kaa tie

choose-IMP.PL2 way

'choose the way' (SINGING)

$S$ BRINGS FOOD TO $R$

$02 \mathrm{R}: \quad j o+k a$ e\#lämä-än vie,

which life-ILL lead.3SG

'which leads to life' (SINGING)

$s$

..+ STROKES R'S HEAD ->

fig

$03 \mathrm{~S}:$

$\# 1$

Ruusa.+

first name

S ---- >+

$04 \mathrm{R}: \quad$ jou+[tu-k-

hurry-IMP.PL2

'hurry-' (SINGING)

$05 \mathrm{~s}$

. + HAND ON R'S SHOULDER --> L. 8

[tääl on ruoka.\#

here be.3SG food

'here is the food.'

---->

fig \#2

06 R: tä.

'what.'

$s \quad-->$

$07 \mathrm{~S}: \quad$ tää-1 on (.) lämmin ruoka.

DEM1-ADE be.3SG warm food

'here is the main course.'

08 R: $\quad$ on-ko tä-ssä ee-ssä.+

be. 3SG-Q DEM1-INE front-INE

'is it here in front'

$09 \mathrm{S:} \quad$ +joo kato täällä.+

yes look. IMP1 DEM1-ADE

'yes look here'

+ HAND FROM R'S SHOULDER TO THE FRONT OF R

$10 \mathrm{~s}: \quad e^{-t-k o,} e^{-}+e^{-}$etkö näe.+

$N E G-2 S G-Q$

see

'don't you see'

$11 \mathrm{~s}: \quad(-)$

DOES STH TO THE FOOD -> L. 15

12 R: mi-llä syödä-än.

Q-ADE eat-PASS

'what do I eat with'

s ------->

$13 \mathrm{~S}:$ tää-lä.

DEM1-ADE 
'with this'

$--->$

15 R: *tä-llä syödä-än +lusika-lla.

DEM1-ADE eat-PAS spoon-ADE

'with this you eat with a spoon'

* LIFTS UP SPOON

$\mathrm{s}$

$17 \mathrm{~S}:$

niin. ole hyvä.+

PRT be-IMP. 2SG good

'yes. here you are'

$----->+$

18 R: +lusika-lla syödä-än.

spoon-ADE eat-

'with the spoon you eat'

S + HAND ON R'S SHOULDER -->

19 S: haaruka-lla. \#+

fork-ADE

'with the fork'

fig

20 S LEAVES

The first touch (line 2, Figure 1) establishes a participation framework (see Goffman 1981: 126-128): it focuses attention on the task at hand and creates a mutual orientation in that situation (see for example, Kendon 1990; Goodwin 2000; Mondada 2009; Cekaite 2016). This occurs when Saara strokes Ruusa's head and only after this initial affectionate contact, Saara uses verbal means to attract attention to the current

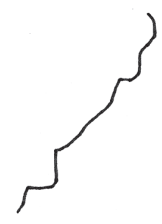

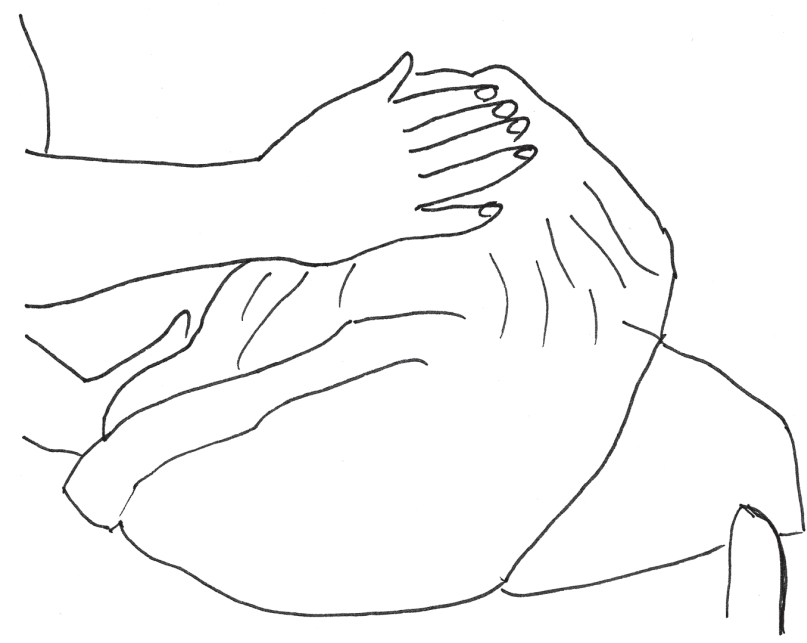

Figure 1: Caregiver strokes resident's head. Example 1, line 2. 
action. Touching initiates their interactional event, mitigates the abruptness of an interruption, and words are used only after embodied action.

The episode occurs during the residents' mealtime while they are sitting together and are served their food. As is reflected in this extract, caregivers generally do not rush the residents. A relaxed atmosphere is fostered by the caregiver's peaceful behaviour: she waits and informs the resident about the food after standing and stroking her (Ruusa) for a moment. Saara has control over the situation, but she gives Ruusa space and displays intimacy when assisting her.

When Saara strokes Ruusa's head, her touch is slow and soft. Touching a resident's head is rather intimate and this occurs rarely in the data - during three encounters - but in this extract, Saara repeats it when asking a question ('don't you see', line 10). This question, and consequently her touch, expresses a strong caring attitude. Especially here, as well as during the entire episode, touching indicates haptic co-presence (Cekaite 2016: 37) and functions as an effective resource in communicating. When Saara tells Ruusa about her food (line 5, Figure 2), Saara puts her hand on Ruusa's shoulder; this also indicates a transition from one action to another (Tulbert and Goodwin 2011: 83). This gentle move shifts from calling attention to the food to specifically requesting Ruusa to eat, which Saara achieves by informing Ruusa about the food.

This extract is an example of how affective touching is coordinated with talk by adjusting relevant participation and simultaneously creating a positive relationship between interactants. Overall, frequent affective touches mitigate the possible negative aspects of overseeing and regulating Ruusa's eating, which becomes prominent when the caregiver guides Ruusa's hand (line 16). In short, affective touching focusses on a positive, intimate atmosphere.

The caregiver in this example closes the discussion by again placing her hand on Ruusa's shoulder (line 19, Figure 3). This type of closing function that touch achieves occurs frequently in conversations, and it can be compared to farewells which conclude "the effect of encounter" (Goffman 1967: 41); laying one's hand on someone's shoulder sums up the friendliness and intimacy between the interactants. Yet the touch that occurs in this context is also conventionalised and it serves a similar function as a teacher's touch in a classroom to encourage a pupil to proceed with an activity (Karvonen et al. 2018).

Touching likewise closes the interaction in the next example. This particular closing is different. After the caregiver, Silja, assists a resident named Rauni to put on her cardigan, Silja stops for a moment to gently

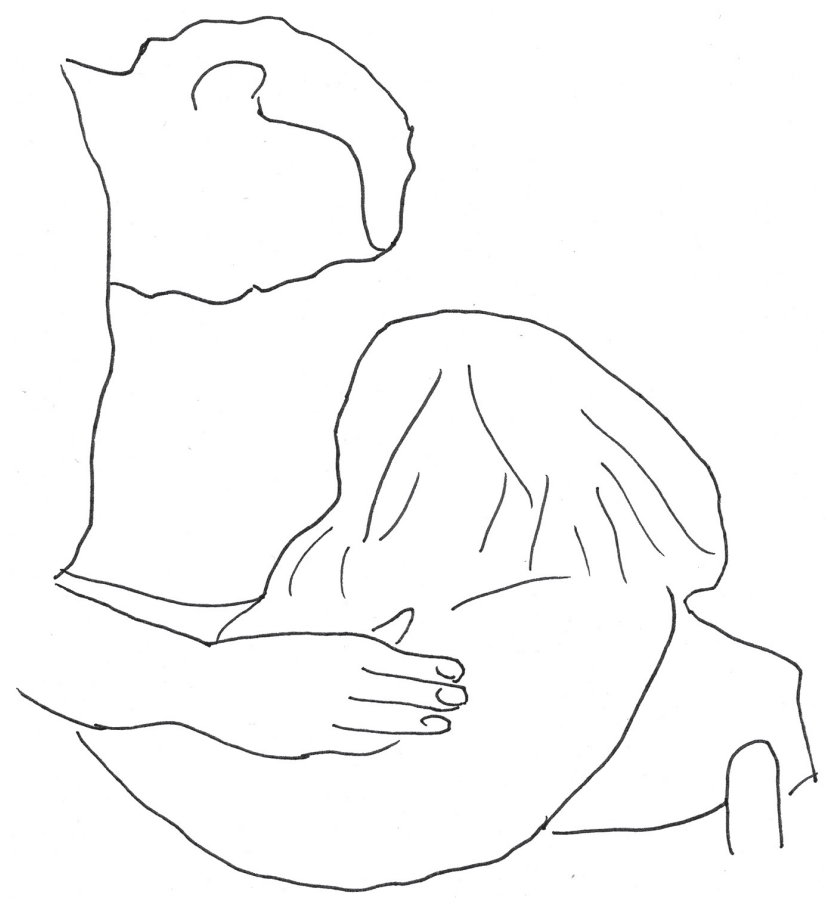

Figure 2: Caregiver touches resident's shoulder. Example 1, line 5. 


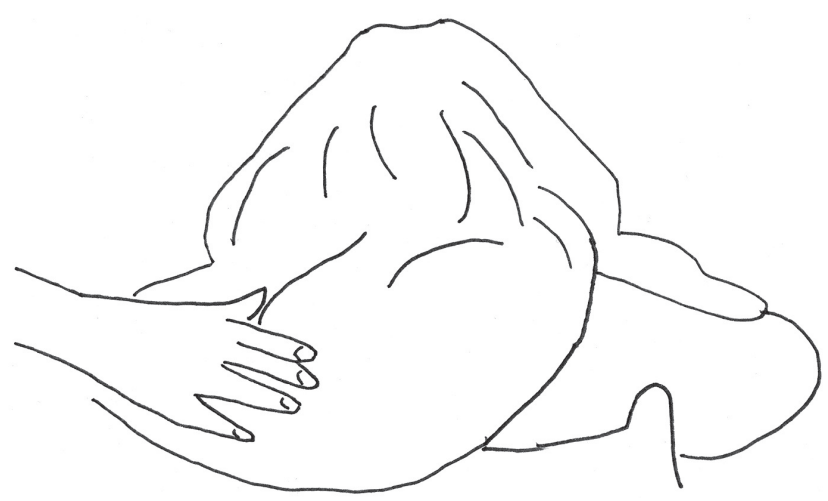

Figure 3: Caregiver leaves. Example 1, line 19.

massage Rauni. Before this extract, Rauni had complained about being cold and Silja guided her to sit down until she brought Rauni her cardigan coat. This entire encounter occurs before breakfast.

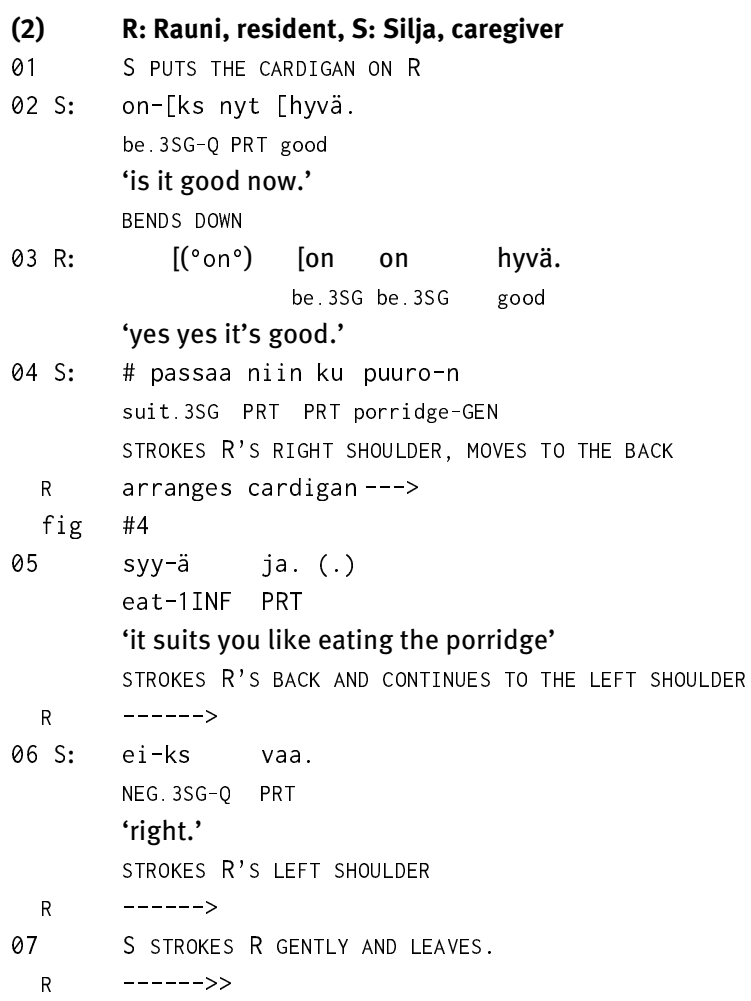

Rauni usually wanders around and her caregivers often need to calm her down. When touching turns, as it does here, into a therapeutic, massage-like activity, it can be considered to be calming, a guiding of Rauni to sit in peace for a while and eat her porridge (line 4-5, Figure 4). Silja's strokes are a continuation of the task already completed, putting Rauni's cardigan on her. Silja does not receive a response to her last statement, which is a tag question (line 6). However, she does not wait for a reply but leaves after lightly stroking Rauni. At the end of an encounter, a more typical touch resembles the one in example 1, when the caregiver only places her hand briefly on the person's shoulder. However, light touch occurs here (line 7) in addition to the massaging, which is also a part of the closing. Rauni usually actively touches her caregivers, which suggests that touching is a natural resource for her. With this in mind, the caregiver's haptic behaviour can be evaluated as even more appropriate. At this point, Rauni does not seem to react and this may be due to her preoccupation with putting on her cardigan. 


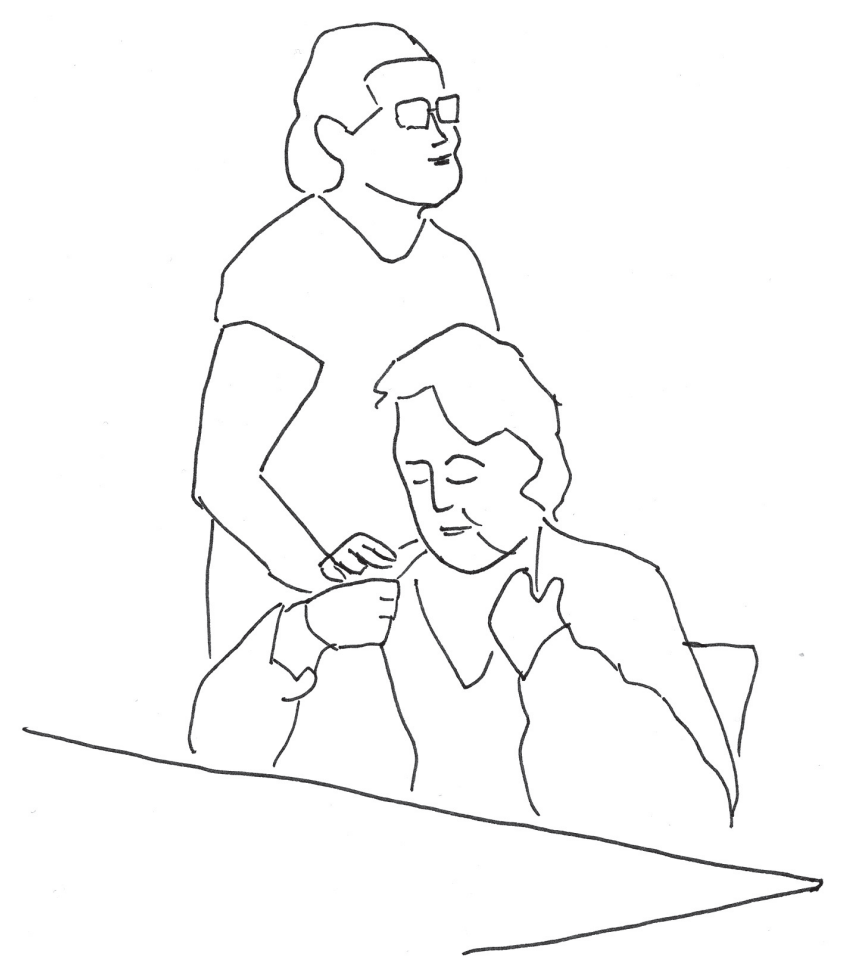

Figure 4: Caregiver strokes resident's right shoulder. Example 2, line 4.

\subsection{Affective touch in interpersonal social action}

The first two examples displayed affective touch in regulating participation and in completing certain activities. The following section illustrates touching as an even more intimate means of constructing a relationship.

In the following (third) example, the resident is Ruusa, as in the first example, but the caregiver is different. In this current example, the resident initiates the encounter by calling for help. Before this extract, the caregiver, Salli, has moved closer to Ruusa. Salli clarifies that she is listening by looking at Ruusa and by asking her what is wrong. However, Ruusa encourages the caregiver to approach even closer and see her. Salli responds in an embodied manner: she not only approaches her but embraces Ruusa during the remainder of the conversation. The embracing lasts 2 minutes and 28 seconds. Prior to the following extract, Ruusa and Salli engaged in a short conversation on Ruusa's physical feeling: Ruusa has stated that she cannot remain standing. At this point, Salli begins to inquire how Ruusa is doing (line 2, Figure 5).

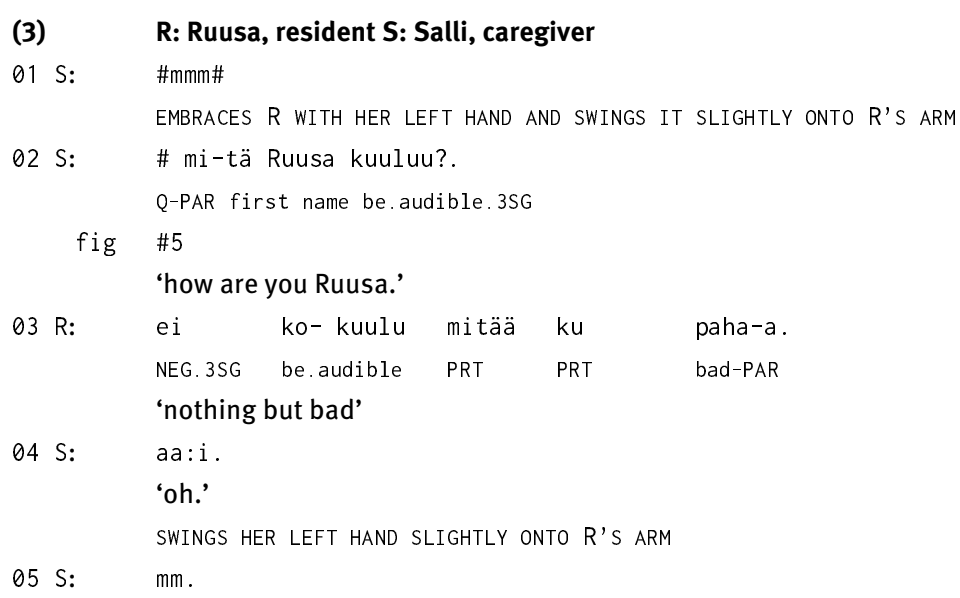




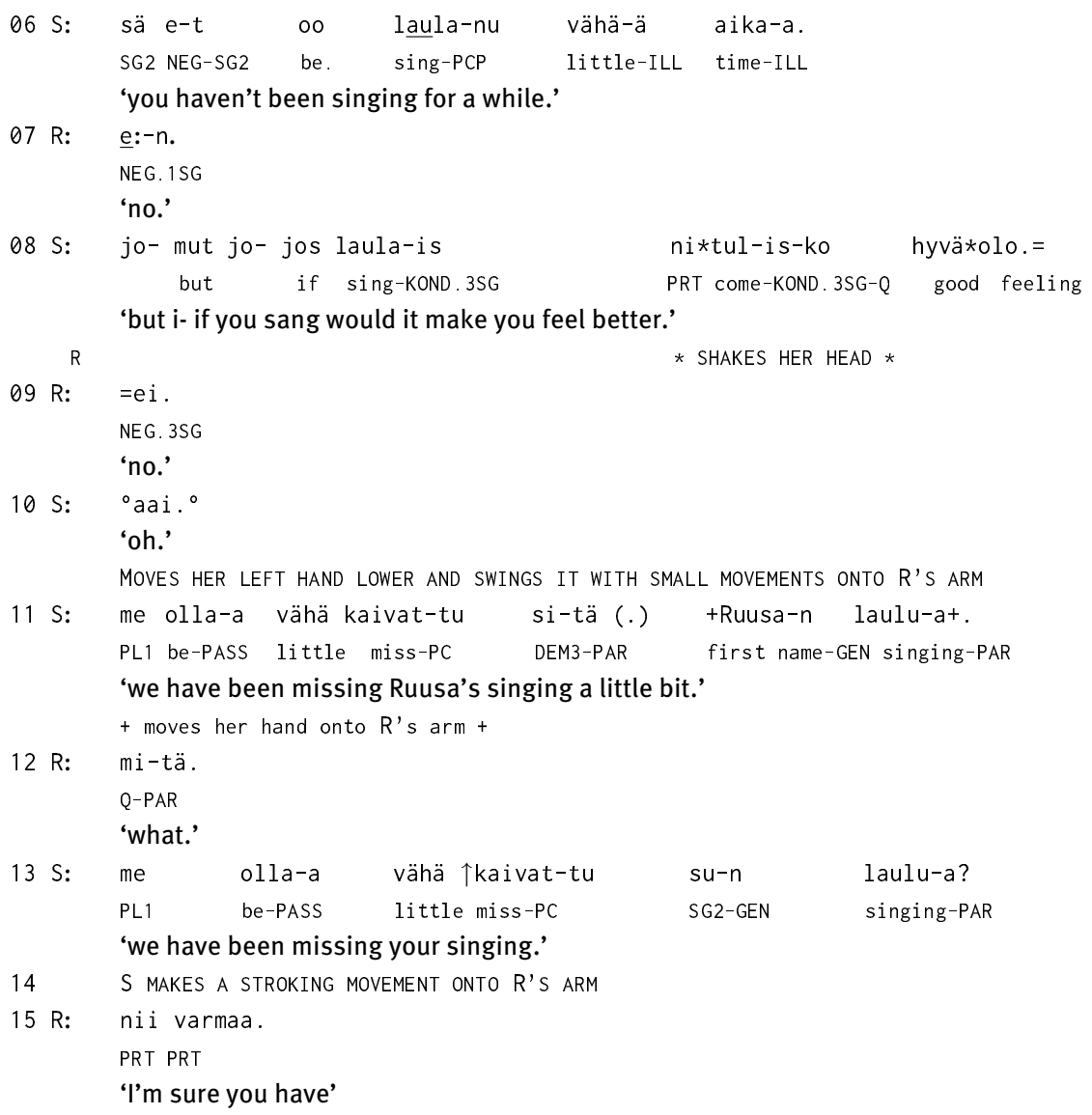

$16 \mathrm{~s}: \mathrm{mm}$.

SWINGS HER LEFT HAND USING SMALL MOVEMENTS ON R'S ARM.

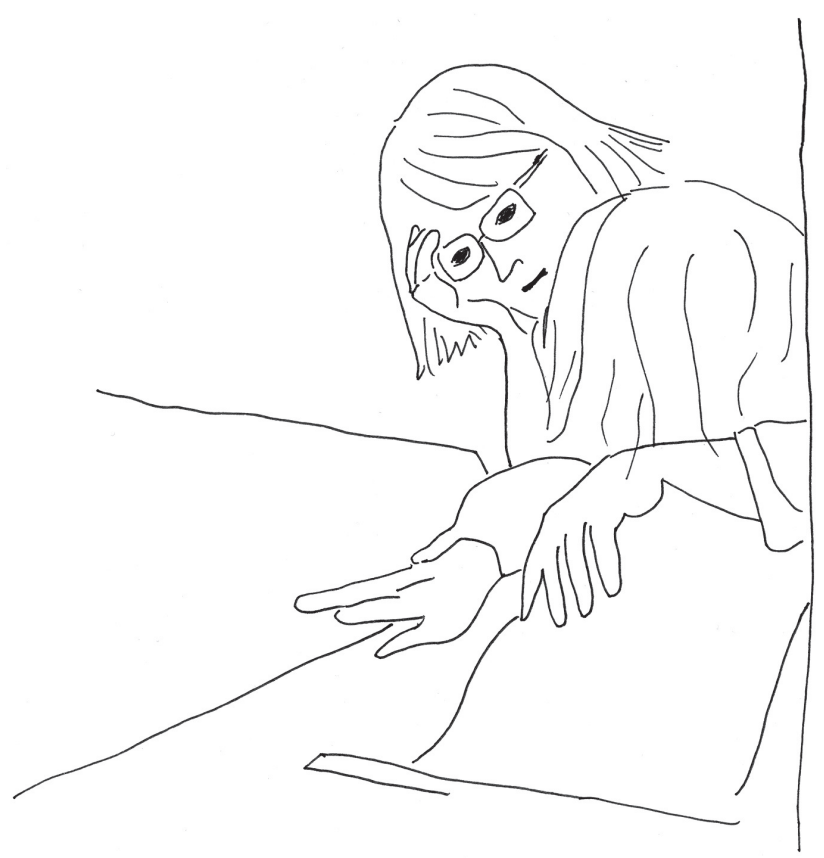

Figure 5: Caregiver embraces resident. Example 3, line 2. 
This extract begins with the caregiver using a slight swinging motion, which resembles cradling, while embracing Ruusa and the caregiver emits a low humming sound (line 1). Salli continues her encounter with Ruusa by using an embodied action that can also be interpreted as filling the gap in their talk (compare Nishizaka and Sunaga 2015: 227). During the entire conversation, their embracing forms an "ecological huddle" (Goffman 1964: 135), which creates a shared, public focus of attention and leaves other people in the room outside momentarily (Goodwin 2007: 57). This episode is about being with Ruusa, and intensive touching supports the main line of their conversation, which is social chatting and making the resident feel better. It is important to note how persistently Salli continues to participate in the situation despite Ruusa's negative reactions to Salli's topics. However, in general, Ruusa also neither resists Salli's embrace nor talk. In the end of the extract, Salli continues the topic of singing and Ruusa responds to her statement by using the particle chain of nii varmaa (I'm sure you have', line 14) where the first particle expresses concession, but the latter particle conveys modal possibility (VISK §1606). This response can be interpreted as an alignment with the caregiver's notion that people miss Ruusa's singing, but it could also be understood as an ironic statement that conveys suspicion of others appreciating her singing.

The swinging movement of Salli's embracing hand can be interpreted as something that intensifies their contact and indicates comfort (compare Cekaite and Holm 2017: 124; Goodwin 2017: 95). The caregiver reacts with this movement to Ruusa's answers: first to Ruusa's negative answer regarding her mood (line 3) and subsequently when Ruusa rejects Salli's suggestion of singing (line 9). Salli also responds to Ruusa's answer to her questions by using the particle $a i$ (VISK § 1049; Koivisto 2016). The first particle (line 4) is especially prolonged and uttered in a sympathetic tone; a swinging movement underlines its function as receiving the negative message with empathy as well as orienting to listening (compare Koivisto 2017). A swinging movement also occurs at the end of this extract when Salli reacts to Ruusa's affirmative (line 15). This movement by Salli, combined with her whole posture of embracing, appears to be comforting and calming in the situation and responds to Ruusa's feelings.

Embodied questioning is a frequently used means of touching in the data. Thus, caregivers ask mundane questions, such as whether or not someone wants coffee, using a half-embrace (Kendon 1990; Cekaite and Holm 2017: 121-123). The use of a half-embrace is typical owing partly to the resident's position in a chair. Some of the caregivers clearly adopt this as their personal style, others maintain their distance more and use other means of affiliation. In addition, placing one's hand on a closer shoulder, as in example 1 (Figure 1), is frequently used in questions. Example 3 represents an intensive case in terms of length as well as the position: the caregiver holds the resident tightly and is very close to her.

\section{Discussion}

This article has focused on the use of touch in constructing relationships between caregivers and care recipients in a care home. My main objective has been to illustrate some means of providing care by examining the moments where touching includes affection. The analysis reveals that affective touch is used as an interactional resource in rich and varying ways when expressing friendliness during assisting residents, which is a natural moment for intimacy. Touch also mitigates face-threatening actions, and emphasizes the positive aspects in encounters. The data provide evidence on how touch was coordinated with talk to accomplish practical tasks but simultaneously to display affection. In interpersonal action, touch is a powerful resource to indicate empathy. Touching is also an intimate way to regulate participation, and it often shifts into caressing and affectionate communication. However, there are obvious discrepancies: on the one hand, institutional care requires distance, but on the other, a care home involves human care, which means also intimacy.

This article was based on the assumption that relational work is an evident part of care and therefore meaningful. In addition, it is clear that friendliness helps to promote the accomplishment of tasks because it is naturally easier to work in a good atmosphere (Backhaus 2011: 134). My analysis demonstrates that touching is an important tool for careworkers to activate interpersonal relationships, but that it does not automatically promote positive aspects, similarly to humour (Heinemann 2009: 124). It seems that caregivers need to be sensitive and communicate their presence in the situation, taking the individual into account. When the staff 
know residents sufficiently well, it is natural to construct a relationship through touching, even in an intimate way - by touching someone's head, stroking and embracing a long time - as in the examples presented.

A common factor that occurs in all of the examples is pausing for some time during tasks, and touch also plays an important role in these contexts. Even when a pause lasts only a few seconds, it indicates presence and orientation to listening, creates a peaceful and accepting atmosphere, and thus is valuable in building a positive relationship. Pausing also has a calming effect on the situation. In example (1), when helping a resident eat, the caregiver waited before talking and used affectionate touch to approach the resident smoothly and to mitigate the controlling aspect of the activity. In the second extract, the resident moved about restlessly, and the caregiver used massage as a partial means to calm her down when closing the encounter, whereas in the third extract, the resident was sitting in her seat but conveyed her restlessness verbally; the caregiver used embracing and a swinging motion as a part of her calming the resident. In extract 1, the caregiver was the initiator of the entire encounter and she obtained the resident's attention by touching. In the others, the residents were active in initiating the encounter. Nonetheless, in all of the cases, the caregivers touch first, which is typical in my data. As for the cases where a resident initiates touch, this is a topic for further research.

All of the examples include direct questions addressed to a resident that are combined with touch. In the first example, the question concerns the resident's sight when touching her head in the middle of the encounter. The second example involves securing that everything is all right while the caregiver bends down and after that, stroking the resident. The last one features the caregiver responding in an intensive embodied way to her resident's claim and beginning to inquire about her resident's feelings instead of closing the encounter quickly. These cases of caregiver-resident interaction are deeper than merely getting the resident's attention because they include a clear interpersonal aspect: the caregiver is present emotionally for the resident.

The analysis of everyday interaction reveals that embodied actions must be interpreted as a part of a context. Touching is used as a multifaceted resource to create affection and presence between a caregiver and resident. For caregivers, touch means balancing between respecting an individual's autonomy and displaying affection and positive emotions but especially by acknowledging the individual differences between the residents.

Funding: The work was funded by the Finnish Work Environment Fund.

\section{Transcription symbols}

$\begin{array}{ll}\cdot & \text { falling intonation } \\ ? & \begin{array}{l}\text { level intonation } \\ \text { rising intonation }\end{array} \\ \text { word } & \text { higher pitch } \\ \text { WORD } & \text { word emphasis indicated by underlining } \\ : & \text { a raise in volume } \\ {[]} & \text { lengthening of a sound } \\ (.) & \text { overlapping speech or action } \\ >< & \text { micropause, less than } 0.2 \mathrm{~s} \\ <> & \text { talk inside is at a faster pace than the surrounding talk } \\ \text { en- } & \text { talk inside is at a slower pace than the surrounding talk } \\ = & \text { cutoff } \\ \# & \text { latched speech, i.e. no silence between two adjacent utterances } \\ { }^{\circ} \text { en } & \text { creaky voice } \\ (-) & \text { talk inside is more quiet than the surrounding talk } \\ (\text { SINGING) } & \text { the words spoken here were too unclear to transcribe }\end{array}$

Multimodal action has been transcribed according to the conventions developed by Lorenza Mondada (see for example Mondada 2009):

* * delimitate a speaker’s gestures and actions descriptions 


$\begin{array}{ll}++ & \begin{array}{l}\text { delimitate another speaker's gestures and actions descriptions } \\ \text { SHAKES HEAD }\end{array} \\ -> & \begin{array}{l}\text { simultaneous embodied action marked under the line } \\ \text { action continues } \\ \text { gesture or action described continues until and after excerpt's end }\end{array} \\ --->> & \begin{array}{l}\text { participant doing gesture is identified in the margin when she is not the speaker } \\ \mathrm{R}\end{array} \\ \text { the exact point where screen shot (Figures) has been taken is indicated, } \\ \text { th } & \text { with a specific sign showing its position within turn at talk }\end{array}$

\section{Names in the extracts}

initial letter $\mathrm{R}$ indicating Resident

initial letter S indicating Staff

\section{References}

Backhaus, Peter. 2009. Politeness in institutional elderly care in Japan: A cross-cultural comparison. Journal of Politeness Research 5. 53-71. https://www.degruyter.com/downloadpdf/j/jplr.2009.5.issue-1/jplr.2009.004/jplr.2009.004.pdf (accessed 29 March 2018).

Backhaus, Peter. 2011. "Me nurse, you resident": Institutional role-play in a Japanese Caring facility. In Peter Backhaus (ed.), Communication in elderly care: Cross-cultural approaches, 129-144. London: Continuum.

Barnett, Kathryn. 1972. A survey of the current utilisation of touch by health team personnel with hospitalized patients. International Journal of Nursing Studies 9. 195-209. http://www.journalofnursingstudies.com/article/0020-7489(72)900338/pdf (accessed 29 March 2018).

de Bot, Kees \& Sinfree Makoni. 2011. Language and aging in multilingual contexts. Clevedon: Multilingual Matters.

Cekaite, Asta. 2015. The coordination of talk and touch in adults' directives to children: Touch and social control. Research on Language and Social Interaction 48(2). 152-175. https://www.tandfonline.com/doi/full/10.1080/08351813.2015.1025501 (accessed 29 March 2018).

Cekaite, Asta. 2016. Touch as social control: Haptic organization of attention in adult-child interactions. Journal of Pragmatics 92. 30-42. https://www.sciencedirect.com/science/article/pii/S0378216615003082?via\%3Dihub (accessed 29 March 2018)

Cekaite, Asta \& Malva Kvist Holm. 2017. The comforting touch: Tactile intimacy and talk in managing children's distress. Research on Language and Social Interaction 50(2). 109-127. https://www.tandfonline.com/doi/pdf/10.1080/08351813. 2017.1301293? needAccess=true (accessed 29 March 2018).

Chochinov, Harvey M., Susan E. McClement, Thomas F. Hack, Nancy A. McKeen, Amanda M. Rach, Pierre Gagnon, Shane Sinclair \& Jill Taylor-Brown. 2013. Health care provider communication. An empirical model of therapeutic effectiveness.Cancer 119(9). 1706-1713. https://onlinelibrary.wiley.com/doi/full/10.1002/cncr.27949 (accessed 29 March 2018).

Coupland, Nikolas 2011: Preface. In Backhaus, Peter (ed.), Communication in elderly care: Cross-cultural approaches, vii-xii. London: Continuum.

Delgado, Cynthia, Dominic Upton, Kristen Ranse, Trentham Furness \& Kim Foster. 2017. Nurses' resilience and the emotional labour of nursing work: An integrative review of empirical literature. International Journal of Nursing Studies 70. 71-88. http://www.journalofnursingstudies.com/article/S0020-7489(17)30042-1/fulltext (accessed 29 March 2018).

Gleeson, Madeline \& Fiona Timmins. 2004a. Touch: A fundamental aspect of communication with older people experiencing dementia. Nursing Older People 16(2). 18-21. http://web.a.ebscohost.com/ehost/detail/detail?vid=0\&sid=e016c468edcb-4dc3-94f8-26618590b8b1\%40sessionmgr4008\&bdata=JnNpdGU9ZWhvc3QtbGI2ZSZzY29wZT1zaXRI\#AN= $12782243 \& \mathrm{db}=\mathrm{a} 9 \mathrm{~h}$ (accessed 29 March 2018).

Gleeson, Madeline \& Fiona Timmins. 2004b. The use of touch to enhance nursing care of older person in longterm mental health care facilities. Journal of Psychiatric and Mental Health Nursing 11. 541-545. https://onlinelibrary.wiley.com/doi/ full/10.1111/j.1365-2850.2004.00757.x (accessed 29 March 2018).

Gleeson, Madeline \& Agnes Higgins. 2009. Touch in mental health nursing: An exploratory study of nurses' views and perceptions. Journal of Psychiatric and Mental Health Nursing 16. 382-389. https://onlinelibrary.wiley.com/doi/full/10.1111/j. 1365-2850.2009.01389.x (accessed 29 March 2018).

Goffman, Erving. 1961. Asylums. Essays on the social situation of mental patients and other inmates. Harmondsworth: Penguin Books.

Goffman, Erving. 1964. The neglected situation. American Anthropologist 66(6). 133-136. https://anthrosource.onlinelibrary. wiley.com/doi/10.1525/aa.1964.66.suppl_3.02a00090 (accessed 29 March 2018).

Goffman, Erving. 1967. Interaction ritual. Essays on face-to-face behavior. New York: Pantheon Books.

Goffman, Erving. 1971. Relations in public: Micro-studies of the public order. New York, NY: Harper and Row. 
Goffman, Erving. 1981. Forms of talk. Oxford: Blackwell.

Goffman, Erving. 1983. The interaction order. American Sociological Association, 1982 Presidential Address. American Sociological Review 1983, 48. 1-17. http://www.jstor.org/stable/2095141 (accessed 29 March 2018).

Goodwin, Charles. 2000. Action and embodiment within situated human interaction. Journal of Pragmatics 32. 1489-1522. https://www.sciencedirect.com/science/article/pii/S037821669900096X?via\%3Dihub (accessed 29 March 2018).

Goodwin, Charles. 2007. Participation, stance and affect in the organization of activities. Discourse \& Society 18(1). 53-73. http://journals.sagepub.com/doi/abs/10.1177/0957926507069457 (accessed 29 March 2018).

Goodwin, Marjorie Harness. 2006. Participation, affect, and trajectory in family directive/response sequences. Text and Talk 26. 515-544.

Goodwin, Marjorie Harness. 2017. Haptic sociality: The embodied interactive construction of intimacy through touch. In Christian Meyer, Jürgen Streeck \& J. Scott Jordan (eds.), Intercorporeality: Emerging socialities in social interaction, 73-102. Oxford, England: Oxford University Press.

Grainger, Karen. 1993. "That's a lovely bath dear." Reality construction in the discourse of elderly care. Journal of Aging Studies 7(3). 247-262. https://www.sciencedirect.com/science/article/pii/089040659390014B?via\%3Dihub (accessed 29 March 2018).

Gumperz, John J. 1982. Discourse strategies. Cambridge: Cambridge University Press.

Gumperz, John J. 2001. Interactional sociolinguistics. A personal perspective. In Deborah Schiffrin, Deborah Tannen \& Heidi Hamilton (eds.), The Handbook of discourse analysis, 215-228. Oxford: Blackwell Publishers. https://www.dawsonera. com/abstract/9780470751985 (accessed 29 March 2018).

Harwood, Jake 2007: Understanding communication and aging: Developing knowledge and awareness. Los Angeles: Sage Publications cop.

Heinemann, Trine. 2007. Professional self-disclosure: When the home help talks about herself. In Catherine Kerbrat-Orecchioni \& Veronique Traverso (eds.), 325-342. Confidence/dévoilement de soi dan l'interaction. Tübingen: Max Niemeyer Verlag.

Heinemann, Trine. 2009. Managing unavoidable conflicts in caretaking of the elderly: Humor as a mitigating resource. International Journal of the Sociology of Language 200.103-127. https://www.degruyter.com/view/j/ijsl.2009.2009.issue200/ijsl.2009.047/ijsl.2009.047.xml (accessed 29 March 2018).

Heinemann, Trine. 2011. From home to institution: Roles, relations and the loss of autonomy in caretaking of the elderly in Denmark. In Backhaus, Peter (ed.), Communication in elderly care: Cross-cultural approaches, 90-111. London: Continuum.

Jansson, Gunilla. 2014. Bridging language barriers in multilingual care encounters. Multilingua 33(1-2). 201-232. https: //www.degruyter.com/view/j/mult.2014.33.issue-1-2/multi-2014-0009/multi-2014-0009.xml (accessed 29 March 2018).

Karvonen, Ulla, Pilvi Heinonen \& Liisa Tainio. 2018. Kosketuksen lukutaitoa. [Literacy of touching. Conventionalized touches in interaction between pupils.] AFinLA Yearbook 75(1). 159-183. https://doi.org/10.30661/afinlavk.69257 (accessed 1 February 2019).

Kendon, Adam. 1990. Conducting interaction. Patterns of behaviour in focused encounters. Cambridge: Cambridge University Press.

Koivisto, Aino. 2016. Receipting information as newsworthy vs. responding to redirection: Finnish news particles aijaa and aha(a). Journal of Pragmatics 104. 163-179. https://www.sciencedirect.com/science/article/pii/S0378216616000540 (accessed 29 March 2018).

Koivisto, Aino. 2017. Uutta tietoa vai oivallus? Eräiden dialogipartikkeleiden tehtävistä. [New information or sudden realisation? On the functions of some response particles in Finnish.] Virittäjä 121(4). 473-499. https://journal.fi/virittaja/article/ view/59297 (accessed 29 March 2018).

Langland, Rose Mary \& Carol L. Panicucci. 1982. Effects of touch on communication with elderly confused clients. Journal of Gerontological Nursing 8(3). 152-155. https://www.healio.com/nursing/journals/jgn/1982-3-8-3/\%7B74b1b78c-4ae04a05-b18c-f7dd9ec2d654\%7D/effects-of-touch-on-communication-with-elderly-confused-clients (accessed 29 March 2018).

Levy-Storms, Lené. 2008. Therapeutic communication training in long-term care institutions: Recommendations for future research. Patient Education and Counseling 73. 8-21. https://www.sciencedirect.com/science/article/pii/ S0738399108002760 (accessed 29 March 2018).

Lindholm, Camilla. 2015. Parallel realities: The interactional management of confabulation in dementia care encounters. Research on Language and Social Interaction 48. 176-199. https://www.tandfonline.com/doi/full/10.1080/08351813. 2015.1025502 (accessed 29 March 2018).

Lindholm, Camilla. 2016. Keskustelunanalyysi ja etnografia [Conversation analysis and ethnography]. In Lindholm, Camilla \& Melisa Stevanovic (eds.), Keskustelunanalyysi: kuinka tutkia sosiaalista toimintaa ja vuorovaikutusta. [Conversation analysis: How to study social action and interaction]. 331-348. Tampere: Vastapaino.

Linell, Per. 2009. Rethinking language, mind, and world dialogically: Interactional and contextual theories of human sensemaking. Charlotte, NC: Information Age Publishing. http://web.a.ebscohost.com/ehost/detail/detail?vid=0\&sid= 281434f5-79b9-4023-b904b04e9a7b2091\%40sessionmgr4009\&bdata=JnNpdGU9ZWhvc3QtbGI2ZSZzY29wZT1zaXRI\# $\mathrm{AN}=470219 \& \mathrm{db}=$ nlebk (accessed 29 March 2018). 
Marsden, Sharon \& Janet Holmes. 2014. Talking to the elderly in New Zealand residential care settings. Journal of Pragmatics 64. 17-34. https://www.sciencedirect.com/science/article/pii/S0378216614000071?via\%3Dihub (accessed 29 March 2018).

Mcllvenny, Paul. 2009. Communicating a "time-out" in parent-child conflict: Embodied interaction, domestic space and discipline in a reality TV parenting programme. Journal of Pragmatics 41. 2017-2032. https://www.sciencedirect.com/science/ article/pii/S0378216608002324?via\%3Dihub (accessed 29 March 2018).

Meyer, Christian, Jürgen Streeck \& J. Scott Jordan. 2017. Introduction. In Christian Meyer, Jürgen Streeck \& J. Scott Jordan (eds.), Intercorporeality: Emerging socialities in social interaction. xv-xlix. Oxford: Oxford University Press.

Mondada, Lorenza. 2009. Emergent focused interactions in public places: A systematic analysis of the multimodal achievement of a common interactional space. Journal of Pragmatics 41. 1977-1997. https://www.sciencedirect.com/science/ article/pii/S0378216608002300 (accessed 29 March 2018).

Nakrem, Sigrid, Anne Guttormsen Vinsnes \& Arnfinn Seim. 2011. Residents' experiences of interpersonal factors in nursing home care: A qualitative study. International Journal of Nursing Studies 48(11). 1357-1366. https://www.sciencedirect. com/science/article/pii/S002074891100229X (accessed 29 March 2018).

Nevile, Maurice. 2015. The embodied turn in research on language and social interaction. Research on Language and Social Interaction 48(2). 121-151. https://doi.org/10.1080/08351813.2015.1025499 (accessed 11 October 2018).

Nishizaka, Aug \& Masafumi Sunaga. 2015. Conversing while massaging. Multidimensional asymmetries of multiple activities in interaction. Research on Language and Social Interaction 48. 220-229. https://www.tandfonline.com/doi/full/10.1080/ 08351813.2015.1025506 (accessed 29 March 2018).

Peräkylä, Anssi \& Melisa Stevanovic. 2016. Kehollinen läsnäolo [Embodied presence]. In Camilla Lindholm \& Melisa Stevanovic (eds.), Keskustelunanalyysi: Kuinka tutkia sosiaalista toimintaa ja vuorovaikutusta. [Conversation analysis: How to study social action and interaction], 32-46. Tampere: Vastapaino.

Routasalo, Pirkko. 1996. Non-necessary touch in the nursing care of elderly people. Journal of Advanced Nursing 23. 904-911. https://onlinelibrary.wiley.com/doi/abs/10.1046/j.1365-2648.1996.00947.x (accessed 29 March 2018).

Ryan, Ellen Bouchard, Mary Lee Hummert \& Linda H. Boich. 1995. Communication predicaments of aging. Patronizing behavior toward older adults. Journal of Language and Social Psychology 14(1-2). 144-166. http://journals.sagepub.com/doi/abs/ 10.1177/0261927X95141008 (accessed 29 March 2018).

Tulbert, Eve \& Marjorie Harness Goodwin. 2011. Choreographies of attention: Multimodality in a routine family activity. In Jürgen Streeck, Charles Goodwin \& Curtis LeBaron (eds.), Embodied interaction. Language and body in the material world, 79-92. Cambridge: Cambridge University Press.

VISK = Hakulinen, Auli, Maria Vilkuna, Riitta Korhonen, Vesa Koivisto, Tarja Riitta Heinonen \& Irja Alho. 2004. Iso suomen kielioppi [The comprehensive grammar of Finnish]. Helsinki: Finnish Literature Society. http://scripta.kotus.fi/visk/ etusivu.php URN:ISBN:978-952-5446-35-7 (accessed 31 January 2018).

Ward, Richard, Antony A. Vass, Neeru Aggarwal, Cydonie Garfield \& Beau Cybyk. 2008. A different story: Exploring patterns of communication in residential dementia care. Aging and Society 28(5). 629-651. https://www.cambridge.org/core/ journals/ageing-and-society/article/different-story-exploring-patterns-of-communication-in-residential-dementiacare/8E6686BCA6FD9FF04ECDD9E853A568B9 (accessed 29 March 2018).

Wilson, Rozanne, Elizabeth Rochon, Alex Mihailidis \& Carol Leonard. 2013. Quantitative analysis of formal caregivers' use of communication strategies while assisting individuals with moderate and severe Alzheimer's disease during oral care. Journal of Communication Disorders 46(3). 249-263. https://www.sciencedirect.com/science/article/pii/ S0021992413000075 (accessed 29 March 2018).

Yu, Doris S. F., Sheung-Tak Cheng \& Jungfang Wang. 2018. Unravelling positive aspects of caregiving in dementia: An integrative review of research literature. International Journal of Nursing Studies 79. 1-26. https://www.sciencedirect.com/ science/article/pii/S0020748917302407 (accessed 29 March 2018). 